\title{
Explaining variation in the implementation of global norms: Gender-mainstreaming of security in the OSCE and the EU
}

Anne Jenichen, Aston University, UK (corresponding author)

Jutta Joachim, Radboud University, Netherlands

Andrea Schneiker, University of Siegen, Germany

\begin{abstract}
Why do regional security organizations choose different approaches to implementing global gender norms? To address this question, we examine how the Organization for Security and Co-operation in Europe (OSCE) and the European Union (EU) integrated requirements derived from UN Security Council Resolution 1325 (UNSCR 1325) on women, peace, and security into their security policies. We identify differences in scope and dynamics between the change processes in both organizations. The OSCE simply adapted its existing gender policy and has not changed it since, whereas the EU introduced a new, more comprehensive and specific policy, which it already has amended several times. Drawing on historical institutionalism and feminist institutionalism, we find that, first, reform coalitions prepared the ground for gendermainstreaming in the organizations' respective security policies, and that, second, embedded policy structures, including rules and norms about external interaction as well as existing policy legacies were responsible for the different approaches of the EU and OSCE with respect to UNSCR 1325.
\end{abstract}

\section{Keywords}

Gender mainstreaming, European Union (EU), feminist historical institutionalism, Organization for Security and Cooperation (OSCE), UN Security Council Resolution 1325 (UNSCR 1325) 


\section{Introduction}

Why do regional security organizations implement global gender norms and principles, and why do they use different approaches? The European Union (EU) and the Organization for Security and Co-operation in Europe (OSCE) are interesting cases that help us answer these questions. Both organizations have engaged with United Nations Security Council Resolution No. 1325 on women, peace, and security (UNSCR 1325), which was adopted on October 31, 2000, and which urges UN member states and UN institutions to (1) increase women's participation and (2) incorporate a gender perspective into all of their peacekeeping and peacebuilding activities at the national, regional, and international levels (UN Security Council, 2000). ${ }^{i}$ However, the EU's and OSCE's implementation approaches with respect to the resolution vary in scope and dynamic. The EU issued a comprehensive policy document and later added indicators to identify concrete steps to turn the policy into practice, whereas the OSCE responded with a comparatively short, not yet amended policy document that lacks concrete indicators for implementation. Beyond these differences related to the resolution, both organizations differ in at least three other respects: (1) size and composition of membership (the EU currently comprises of 28 member states, while the OSCE counts 57 states from Europe, the South Caucasus, Central Asia, Russia and North America); (2) approaches towards security (the OSCE's concept of comprehensive security embraces not only a politico-military dimension, but also an economic and environmental as well as a human dimension, the latter including issues of human rights, tolerance and non-discrimination and challenging traditional notions of security undergirding the EU's security and defense policy); and (3) varying opportunity structures of both organizations with that of the EU being more accessible for civil society actors than that of the OSCE. Given these institutional differences between the EU and the OSCE, we are interested in how they have shaped implementation of UNSCR 1325 in the security policies of both organizations. 
Drawing on conventional and feminist historical institutionalism, we argue that the different ways in which the EU and the OSCE engaged with UNSCR 1325 can be explained by their existing (gendered) institutional norms and rules and by the networks of gender advocates from within and outside the two organizations. Our findings add to the more general literature on gender-mainstreaming, which has paid scant attention to the domain of security. More specifically, they also contribute to the existing body of knowledge in this area, which has focused mainly on single case studies (e.g., Guerrina and Wright, 2016; Wright, 2016). Our comparison of the EU and the OSCE will provide insights into the scope conditions of gendermainstreaming - that is, the circumstances in which inserting gender into a less favorable policy domain becomes possible, and how this happens.

Our exploration of norm implementation in the OSCE and the EU, at the policy as opposed to the field level, is based on a qualitative document analysis and on semi-structured interviews. With the aim to identify relevant events, policies and actors involved in the implementation of UNSCR 1325, we systematically reviewed all documents issued by EU and OSCE institutions, and by civil society actors, related to the process. Moreover, we conducted interviews between March 2009 and January 2016 with 14 individuals, selected on the basis of recommendations and of the information we obtained from the document analysis. They included four current and former OSCE officials, two EU officials, four civil society actors, three state representatives from Sweden and Germany and one representative of UN Women. The interviews helped not only to further reconstruct the implementation processes, but also to determine the role of different actors, their positions, the strategies they pursued and the constraints they faced.

The article is structured as follows: First, we identify aspects of historical institutionalism that are relevant to our comparison of policy change in regional security organizations and discuss the added value a feminist lens can contribute to such a perspective. Drawing on these ideas 
and concepts, we then explore why the OSCE and the EU embraced UNSCR 1325 in different ways. After briefly describing the major differences between the relevant policies of the two organizations, we discuss specific reasons why their implementation paths diverged, such as the different composition of reform coalitions reflecting different formal and informal rules for external interaction, distinct policy legacies, and differences in the impact of decision-making structures as a result of varying extent of membership. We conclude with some reflections on theoretical and practical implications.

\section{Feminist historical institutionalism and change within international organizations}

Historical institutionalism (HI) is a particularly useful perspective to study change within international organizations. Not only does it go beyond the scope of rational choice institutionalism, which focuses primarily on the power and instrumental rationale of member states (e.g., Hawkins et al., 2006); it also exhibits more dynamism than the sociological strand of institutionalism that informs constructivist approaches focusing on bureaucracies of international organizations and their particular cultures (e.g., Barnett and Finnemore, 2004).

HI helps us understand how institutions develop over time, under what conditions policy paradigms become embedded, and why political actors stick to institutional designs once they have invested in them (see Fioretos, 2011). It is precisely for these reasons that it is useful for investigating why the OSCE's and the EU's ways of implementing UNSCR 1325 diverge. Moreover, HI offers a notion of incremental change that conforms to how gendermainstreaming has been found to proceed. However, rather than drawing exclusively on HI, our analysis is also informed by its feminist variant, which 'critiques and seeks to overcome the gender blindness of existing scholarship in the field' and 'responds to the considerable analytical strengths of [historical institutionalism] and the potential use of new institutionalist concepts and tools to help answer key questions of concern to feminist political scientists' 
(Mackay, Kenny, and Chappell, 2010: 574). Feminist historical institutionalism shares many assumptions with its precursor, but also goes beyond conventional $\mathrm{HI}$ in at least one important respect-rather than viewing institutional norms and rules as neutral, feminist historical institutionalists regard them as inherently gendered.

HI builds on the premise that institutional rules and norms agreed upon in the past develop path-dependent effects and will influence decisions and courses of events in the future. Proponents of the approach, most prominently Paul Pierson, explain path-dependence primarily by the dynamics of increasing returns and positive feedback. According to Pierson, these dynamics emerge when 'the relative benefits of the current activity compared with other possible options increase over time' and 'the costs of exit-of switching to some previously plausible alternative_-rise' as a result (Pierson, 2000: 252), thus creating support for existing designs and resistance to change among constituencies. Organizations may even experience lock-in effects if '(i)nstitutions [...] lock in balances of power or policy paradigms for lengthy periods of time and thus give those in privileged positions [...] a stake in protecting extant designs' (Fioretos, 2011: 377). In addition to vested interests, cognitive effects—such as learning, which leads to the continuance of established practices, and adapting expectations to the status quo — can contribute to the upholding of once established institutions (Zürn, 2016: 209-210).

Feminist historical institutionalists have called attention to the fact that institutions are inherently gendered. In their view, constructions of masculinity and femininity- that is, notions of how women and men are and should be, and what roles they should or should not assume - are embedded in the logics of political institutions, which constrain and shape social interaction (Mackay, Kenny, and Chappell, 2010: 580). These constructions manifest themselves in two ways: nominally, in the distribution of power between men and women, and substantively, through deeply embedded ideas of gender roles and relations. Historically, 
'entrenched gender stereotypes and control of political resources have worked to privilege [certain] men and disadvantage most women' (Chappell and Waylen, 2013: 602). This becomes particularly clear when considering the military and the police. Premised on gendered norms and practices, these security institutions are characterized by a reinforcement of paternalistic masculinities - men as protectors of allegedly powerless women and childrenand the exclusion of women (Sjoberg, 2013). Although the formal rules for women's access to the police and the armed forces have changed practically everywhere and the numbers of women in these institutions have increased as a result, 'norms related to masculinity remain embedded in the organizations and their practices and become a challenge for women's inclusion and performance' (Kronsell, 2016: 515).

Gendered informal norms and rules that disadvantage women have proved to be persistent (or 'sticky,' as historical institutionalists call it), despite attempts by feminist reformers to challenge them. They exist alongside and in conjunction with formal institutions and, according to feminist historical institutionalists, are the reason 'changes to formal rules do not always mean that institutions act in ways designers anticipated or wanted, as informal norms, rules, and procedures are very powerful—particularly in terms of gender-and may undermine formal changes' (Chappell and Waylen, 2013: 603).

Because of this entrenched nature of institutions, change will often come incrementally. For example, organizations gradually replace old rules with new ones (displacement), add new rules to existing ones (layering), interpret and enact existing rules in new ways (conversion), or leave rules formally in place while still being faced with changes resulting from shifts in external conditions (drift) (Mahoney and Thelen, 2010: 15-18). According to historical institutionalists, more radical institutional change only results from exogenous shocks, or from what institutionalist scholars refer to as 'critical junctures' (Capoccia and Kelemen, 2007). In the absence of such events, incremental change may be initiated by reform coalitions. However, 
the success and achievements of such coalitions are shaped by existing formal and informal rules in the organization (Hanrieder, 2014; Mahoney and Thelen, 2010; Moschella and Vetterlein, 2014; Waylen, 2009).

The importance of internal and external norm advocates as major drivers of change has been highlighted not only by HI but also by previous research on change within international organizations (e.g., Elgström, 2000; Park, 2006). One concept often discussed in the context of gender equality policy in the EU is Woodward's feminist constellation of 'velvet triangles,' which consist of actors from 'the organizations of the state, of civil society, and [...] universities and consultancies' (Woodward, 2003: 84) who constantly push for the introduction of gender into EU policy-making in a variety of domains (see also Woodward and van der Vleuten, 2014). Actors from organizations of the state include representatives of national governments and supranational institutions (i.e., of member states and the bureaucracy of the international organization), whereas the second and third groups include activists and experts from outside of the organization. The importance of external interaction is also addressed by proponents of both conventional and feminist HI. They emphasize that cooperation between internal reform coalitions and external actors is important. It allows new ideas and additional resources to access the policy process, which often leads to more substantial change (Hanrieder, 2014; Moschella and Vetterlein, 2014; Waylen, 2009), whereas '[i]n the absence of external stimuli, the actors involved in the decision-making process tend to rely on what they know and on the instruments they have experience with' (Moschella and Vetterlein, 2014: 151). Thus, it can be assumed that formal and informal rules that define an international organization's degree of openness influence implementation processes, in that they facilitate access to the policy process for external actors from other international organizations, civil society, and academia. The strategies of reform coalitions and the outcomes they can achieve are shaped not only by the composition of reform coalitions and the opportunity structures which they faced in an 
organization, but also by existing policies, norms, and ideas. Feminist institutionalists have stressed that persistent gender norms and unequal power relations between women and men 'are part of the wider legacies and ongoing dynamics with which reform efforts must contend' (Mackay, Kenny and Chappell, 2010: 585), which usually prevent transformative gender change. However, gendered institutional legacies do not always act as constraints, they can also provide opportunities. For instance, if policy environments are already relatively open to gender equality issues, they can enable reform coalitions to capitalize on the predominating political climate within the organization and use existing gender equality norms and policies to pursue their concerns (Waylen, 2009). Policy legacies, as our case studies will demonstrate, can impede change, but they can also be catalysts for new ideas, particularly when actors from within an organization maintain relationships with and engage in external networks. Finally, the institutional context can also manifest itself in decision-making rules, which determine the veto power of opponents to change (Hanrieder, 2014). Both of the organizations we examine here are subject to the consensus rule, which makes lock-in effects particularly likely to occur, considering that individual member states can obstruct change by blocking decisions. However, given the differences in membership between these organizations, which is more limited in the EU than in the OSCE, we would still expect this rule to play out differently.

With these historical institutionalist concepts and assumptions in mind, we now turn to the comparison of the OSCE and the EU. Our analysis will illustrate how feminist reform coalitions in the two organizations prepared the ground for the implementation of UNSCR 1325 by working hard to overcome 'sticky' norms regarding women's exclusion from areas of 'traditional' security, such as police and military issues. However, the outcomes they achieved differed in several respects which, as we will show, can be convincingly explained with reference to existing institutional contexts: Different opportunity structures for external 
interaction, distinct gender policy legacies, and different memberships shaped and constrained change agents and change in the EU and the OSCE, and, thus, help us to identify scope conditions of gender-mainstreaming in regional security organizations.

\section{The different approaches of the OSCE and the EU to implement UNSCR 1325}

The approaches that the OSCE and the EU have chosen to integrate UNSCR 1325 into their security policies differ by type, scope, and dynamic. With reference to conceptualizations of incremental change within HI described above, we might interpret the OSCE's approach as conversion that has become stagnant (or locked in), whereas the EU's approach might be regarded as a form of layering, albeit one that has been both more comprehensive and specific, and that is still evolving.

The way the OSCE implemented UNSCR 1325 can be characterized as a form of conversion that Mahoney and Thelen define as 'changed enactment of existing rules due to their strategic redeployment' (Mahoney and Thelen, 2010: 16). The OSCE primarily used its existing gender policy to implement UNSCR 1325. It had introduced its first Gender Action Plan in June 2000, a few months before UNSCR 1325 was adopted. Unlike in the case of the EU, gender had already been introduced into the organization's security policy, yet its implementation was limited to the human dimension - that is, to issues of democratization and human rights. In the politico-military dimension, by contrast, gender activities had been a rare occurrence (see OSCE Annual Reports, 2000-2005). Even though the OSCE played an important role in broadening traditional concepts of security by adding a human dimension, prior to UNSCR 1325 this did not go hand in hand with challenging traditional notions of gender in all dimensions. Overall, UNSCR 1325 had not received much attention until 2005. Although the OSCE acknowledged its adoption in its 2001 Annual Report and, in its second Gender Action 
Plan of 2004, urged member states to comply with it, it did not specify what exactly this would involve in terms of policy and practice.

This tentative conversion process is reflected in the principal implementation document - the Ministerial Council Decision on women in conflict prevention, crisis management and postconflict rehabilitation adopted in 2005-which defines the primary objective as '(e)nsuring proactive implementation throughout the Organization of the 2004 OSCE Action Plan for the Promotion of Gender Equality' (OSCE, 2005: Art. 1). Only secondary to this is the objective of '[i]ntegrating into the activities of the OSCE, as appropriate, the relevant parts of UN Security Council resolution 1325 (2000) on the role of women in all levels of conflict prevention, crisis management and resolution, and post-conflict rehabilitation' (Art. 2). The Decision includes seven articles that call on OSCE member states to increase the number of women in OSCE institutions and field missions, particularly in senior positions (Arts. 3-5); to promote women's participation in peacebuilding initiatives and political processes, as well as in conflict prevention, conflict resolution, and post-conflict rehabilitation (Arts. 6-7); to consider women's and girls' important roles and particular needs when dealing with refugees and internally displaced persons (Art. 8); and to 'regularly evaluate their efforts at gender mainstreaming in conflict prevention, conflict management, and rehabilitation processes' (Art. 9). To varying degrees, these objectives had already been formulated in the OSCE's second Gender Action Plan; the Ministerial Council Decision merely linked them more explicitly to the areas of conflict prevention, crisis management, and conflict rehabilitation, thus 'converting' them to align also with the politico-military dimension of the organization's security policy.

Following the Decision's adoption, the OSCE launched a variety of gender activities in the politico-military dimension, including the appointment of a Gender Advisori ${ }^{\mathrm{ii}}$; the publication of handbooks and toolkits on gender and security sector reform, gender-responsive mediation, 
and internal oversight in the armed forces and the police; direct contributions to the development of National Action Plans in participating states; and trainings and support for national reform processes in the areas of women's representation and gender-mainstreaming in the police, the army, and border security agencies (Ormhaug, 2014: 34-37; OSCE Annual Reports, 2005-2015). However, according to Lukatela (2016), the limited scope and specificity of the Ministerial Council Decision of 2005 provided a weak basis for the implementation of UNSCR 1325. As of yet, the existing policy framework has not been amended, despite calls from representatives from the OSCE and civil society at the OSCE Security Days event In Pursuit of Peace and Security: How Gender Makes a Difference in November 2015 to develop an 'own action plan to integrate the Women, Peace and Security agenda more efficiently into the OSCE policies' (OSCE, 2015: 7).

The EU's approach started from very different premises but has been more comprehensive, specific, and dynamic than that of the OSCE. The EU's early gender equality policy initiatives in the 1970s and 1980s were limited to employment and the EU's internal dimension. In the course of the policy's expansion during the 1990s, gender issues received increasing attention in the EU's external affairs, but with a special focus on development cooperation only. As a result, gender has mostly been an issue linked to the Common Market and to development assistance, areas in which the European Commission is a central player and in which until today most of the resources for gender equality issues are located (European Parliament, 2009: 43). The European Security and Defense Policy (ESDP), by contrast, has been characterized by a 'persistent invisibility of gender' (Weiner and McRae, 2014), and it was not until 2006 that the Council responded to the continued appeals of the European Parliament to increase women's participation in peaceful conflict resolution (European Parliament, 2000).

Beginning in 2006, the EU, unlike the OSCE, introduced a new gender policy into its ESDP, thus layering 'new rules on top of or alongside existing ones' (Mahoney and Thelen, 2010: 15). 
In 2006, the Council issued a Check List to ensure gender mainstreaming and implementation of UNSCR 1325 in the planning and conduct of ESDP operations (Council of the European Union, 2006). Whereas this Checklist had been vague and noncommittal (Gya, 2007: 6), the in 2008 adopted Comprehensive approach to the EU implementation of the United Nations Security Council Resolutions 1325 and 1820 on women, peace and security (Council of the European Union, 2008) was much clearer and precise. The 43-page policy document envisioned a three-pronged strategy 'to protect, support, and empower women in conflict', calling on EU member states to 'integrate women, peace and security issues in its [the EU's] political and policy dialogue with partner governments, particularly of countries affected by armed conflict, in post conflict situations or situations of fragility'; to 'mainstream a gender equality approach in its policies and activities, especially in the context of crisis management and in its long-term development cooperation'; and to 'support specific strategic actions [...] targeted at protecting, supporting and empowering women' (Council of the European Union, 2008: 11). The second point reveals the EU's broader understanding of gender-mainstreaming in security particularly well. Whereas the OSCE's Ministerial Council Decision focuses primarily on women's participation, which is also reflected in the way its own gender policy was implemented (see, e.g., the OSCE Annual Reports, 2000-2015), the EU's Comprehensive Approach identifies mainstreaming a gender equality perspective as an important goal. Moreover, it specifies a range of measures to implement UNSCR 1325 (and 1820), an effort that is completely absent in the OSCE's document.

The Council has adopted several strategies since 2008 that might be regarded as central to its implementation of UNSCR 1325 and as complementary to the Comprehensive Approach, in that they identify concrete steps for how to achieve gender-mainstreaming in the context of the ESDP. These steps include a set of Indicators for the Comprehensive Approach to the EU implementation of the United Nations Security Council Resolutions 1325 and 1820 on women, 
peace and security (Council of the European Union, 2010), which were revised in 2016. ${ }^{\mathrm{ii}}$ In addition, the Comprehensive Approach established an Informal Task Force on UNSCR 1325, which meets regularly with the EU Special Representative on Human Rights, the Crisis Management and Planning Directorate, and the Civilian Planning and Conduct Capability of the European External Action Service (EEAS). It consists of members of the EEAS, the Council secretariat, and the Commission and is open to participation of member states and civil society organizations, which makes it an 'important entry point for feminist advocacy' (Guerrina and Wright, 2016: 304). Moreover, in 2015, the EEAS introduced the position of a Gender Advisor, although it should be noted that it did so after having resisted the creation of a Special Representative on Women, Peace, and Security (Guerrina and Wright, 2016: 310). As we have seen, the OSCE and the EU chose different approaches to implementing UNSCR 1325. The OSCE adapted (or 'converted') its existing gender policy to a new policy area (i.e., that of 'traditional' politico-military security), selected a fairly limited approach to gendermainstreaming that was based primarily on women's participation, and for quite some time now has experienced a 'lock-in' of this policy paradigm. The EU, by contrast, 'layered' a new gender-mainstreaming policy on top of existing ones in other policy areas and chose a more comprehensive and specific approach that has since been evolving. In the following section, we will draw on feminist HI to provide some explanations for these diverging implementation paths.

\section{Explanations for diverging implementation paths}

Feminist historical institutionalism helps us understand why the OSCE and the EU started to address UNSCR 1325, despite 'sticky' norms on women's exclusion from 'traditional' security, and why the two organizations chose different approaches to implementing it. It draws attention to several factors: feminist reform coalitions, which were the main drivers behind the 
engagement with the resolution in both organizations; and specific institutional constraints, which produced path-dependent responses. Increasing participation of external actors in the EU's reform coalition, which reflects different rules for external interaction, permitted the influx of new ideas into the process of implementing UNSCR 1325. This explains, at least in part, the larger scope of the EU's approach. In comparison, the decision of the OSCE's gender bureaucracy to stick to existing policy rather than introducing a new one as favored in the case of the ESDP, is the result of distinct gender policy legacies which shaped the strategies of reform coalitions and member states' responses to their demands in different ways . Finally, more open opposition to the integration of UNSCR 1325 in the OSCE and the prevailing consensus rule resulted in a lock-in of the OSCE's policy framework, whereas the implementation of the resolution in the EU was not hindered by veto players in this manner.

\subsection{Feminist reform coalitions, their composition, and rules for external interaction}

Feminist historical institutionalists have emphasized, and others have discussed with regard to the EU and the OSCE (Guerrina and Wright, 2016; Kronsell, 2016; Lukatela, 2016), that entrenched male power makes security institutions particularly resistant to gender equality. For this reason, feminist reform coalitions and individual change agents were necessary for both organizations to address UNSCR 1325. However, the coalition in the EU differed from that in the OSCE. It included more external actors, among them NGOs, and therefore was more akin to a "velvet triangle"” (Woodward, 2003), commonly seen as so important for gender equality change, than the coalition in the OSCE. The broader coalition in the EU is reflective of the fact that the organization has started to formally institutionalize contacts with NGOs and civil society organizations in the field of security (Dembinski and Joachim, 2014). .. Accordingly, the reform coalition in the EU included not only the European Parliament and individual member states, such as France and Slovenia, but also UN agencies, such as UNIFEM, and civil 
society actors. ${ }^{\text {iv }}$ The latter particularly added momentum to the gender-mainstreaming of security and defense by pushing 'the EU to the effective implementation of benchmarks for 1325' (European Parliament, 2010: 19), the development of indicators on sexual violence, and the continuation of 'ongoing consultations already existing for a few years in the EU institutions with NGOs, civil society, and UN agencies' (European Parliament, 2009: 42). Two civil society organizations assumed prominent roles in this respect. The International Security Information Service (ISIS) Europe, a research and advisory organization in the field of European and international security and defense, was commissioned by EU institutions to write reports, provided feedback on the implementation process, and offered recommendations. The European Peacebuilding Liaison Office (EPLO), a platform for European NGOs, networks, and think tanks, acted as a clearing house that documented and provided information about EU policy initiatives and offered policy advice and specific recommendations. ${ }^{\mathrm{v}}$

In addition, the network of gender entrepreneurs in the EU was joined by prominent individuals who were members of different networks themselves and who were akin to the 'change agents' that Woodward and van der Vleuten regarded as crucial in the promotion of 'gender equality norms and practices' in the EU more generally (Woodward and van der Vleuten, 2014: 76). Margot Wallström might be regarded as such an entrepreneur and 'active broker.' She travelled between, and was familiar with, both the EU and the UN because of her previous appointment as EU Commissioner for Environment and, later, UN Special Representative on Sexual Violence in Conflict. She frequently attended EU meetings and consultations with Council and Commission staff and with civil society organizations devoted to issues related to gender and armed conflict (see European Parliament, 2010: 10). According to a report for the European Parliament, 'Wallström decided to work [...] in a proactive direction and provided, via a newly established Team of Legal Experts, international assistance to institutional and capacity 
building' (European Parliament, 2010: 16). She also called for a 'Personal (EU) Advisor to act as a Personal Interlocutor' to her role (European Parliament, 2010: 48).

Another important change agent in the EU was Brigadier General Karl Engelbrektsson. As a member of the Swedish Armed Forces, a former commander of the Nordic Battle Groups, and the Swedish representative to the EU Military Committee, Engelbrektsson was 'a strong voice in the military for 1325 to become a natural approach to EU policy implementation' (European Parliament, 2010: 62) and a promoter of gender coaching for head of missions (European Parliament, 2010: 62). However, the EU's openness and receptiveness to external actors such as Wallström and Engelbrektsson, as well as to the UN and civil society organizations, can be explained not only by access rules but also by the lack of in-house expertise on how to include gender-mainstreaming into security policy. ${ }^{\mathrm{vi}}$

In contrast to the EU, in the OSCE, despite gradual improvement of opportunity structures for NGOs since the 1990s, with NGOs now being able to attend most official OSCE meetings, 'there have been no successful attempts to entrench formal access, nor do they seem likely' (Squatrito, Sommerer, and Tallberg, 2016: 187). As a consequence, civil society organizations have not really been part of the reform coalition that shaped OSCE policy on the resolution. The gender bureaucracy in Vienna involved NGOs only occasionally, through invitations to events related to the issue and in the context of specific projects concerning the development of UNSCR 1325 National Action Plans in participating states in which the independent research foundation Peace Research Institute Oslo (PRIO) and the international NGO Inclusive Security took part as project partners (Ormhaug, 2014; OSCE and Inclusive Security, 2016). ${ }^{\mathrm{vii}}$ The OSCE had already developed its own internal gender bureaucracy before it implemented UNSCR 1325 and apparently did no longer regard external gender expertise as necessary.

The UNSCR 1325 reform coalition in the OSCE consisted mainly of internal actors, with the Swedish delegation leading the way by initiating the Ministerial Council Decision in 2005 and, 
since 2011, funding the separate Gender Advisor within the OSCE Secretariat responsible for gender equality issues within the politico-military dimension. This Adviser, Swedish herself, became one of the major drivers behind the implementation of UNSCR 1325 within the organization. The Swedish delegation was supported by the Vice-President and Special Representative for Gender Issues of the OSCE Parliamentary Assembly (and former ViceChairperson of the Defense Committee of the Swedish Parliament), the Folke Bernadotte Academy (a Swedish government agency for peace, security, and development), and a few other OSCE delegations.

The leadership of Swedish actors in both organizations can be explained by Sweden's strong gender-mainstreaming agenda and policies on the domestic level. The Swedish government, for instance, was one of the first governments to adopt a national gender action plan concerning UNSCR 1325, it worked with civil society organizations and the military to develop mechanisms for more inclusion of gender issues in peacekeeping missions, and made achieving equality of women and men a fundamental aim of its foreign policy. ${ }^{\text {viii }}$ Supporting the implementation of UNSCR 1325 in the OSCE and the EU was an important part of this agenda.

\subsection{Distinct gender policy legacies}

The reform coalitions in the OSCE and the EU encountered distinct gender policy legacies that shaped their strategies and member states' responses in different ways, and thus produced pathdependent effects in both organizations.

In the OSCE, the already existing gender policy and different understandings of gender issues and UNSCR 1325 had lasting effects on the integration of the resolution. The fact that a gender policy was already in place led many policy-makers within the OSCE to believe that their organization did not need UNSCR 1325. According to some of our interviewees, many government officials from participating states did not understand why yet 'another' gender 
policy would be needed. In addition, many officials insisted that gender issues were a matter of the human dimension of security — that is, of democracy and human rights — rather than a matter of the politico-military sphere, a view that reflected the then established practice of implementing the existing gender policy almost exclusively in the human dimension of the OSCE's security policy. Many also considered the resolution to be a UN policy on peacekeeping that was irrelevant to the OSCE's activities, which focus primarily on postconflict situations and do not include military operations. ${ }^{\text {ix }}$ Our findings, based on what interviewees told us, suggest that the preferences of many participating states to continue established practices can be explained by cognitive effects, such as 'learned' practices and understandings, rather than vested interests in established designs and turf wars within the organization.

For this reason, the then OSCE Gender Advisor adapted her approach to the resolution accordingly. She preferred to introduce UNSCR 1325 into the OSCE with reference to the organization's existing concept of comprehensive security by extending gender from the human to the politico-military dimension, instead of trying to set up a separate policy for UNSCR 1325. ${ }^{\mathrm{x}}$ This way of thinking was reflected in the organization's second Gender Action Plan, which suggested extending the comprehensive security approach to include gender based on the idea that '[g]ender equality contributes to comprehensive security, which is a goal of OSCE activities in all three dimensions' (OSCE, 2004: para. 3), and that '[t]he empowerment of women in the political-military dimension is also essential to comprehensive security' (para. 44e). In a background paper published later, the organization explained that 'the OSCE has adopted some of the provisions of UNSCR 1325 directly, [while] "customizing" others to its specific mandate and its comprehensive approach on security' (OSCE, 2010: 1). The ESDP did not have a gender policy prior to the adoption of UNSCR 1325 . Therefore, the reform coalition did not encounter arguments from member states similar to those in the OSCE. 
However, it drew on already existing gender policies in fields other than security to make a case for the new policy on UNSCR 1325 . Feminist historical institutionalism reminds us that it is the institutional substrate that enables organizations to differentiate themselves from others in the first place, or as Koops puts it, 'to build up [their] own image, identity, and reputation' (2012: 174). The high degree of institutionalization of gender allowed the EU to distinguish itself from other organizations, with UNSCR 1325 being considered as a means to 'improve EU visibility' (Council of the European Union, 2010: 7). Several internal documents support this finding, including a study prepared by Sherriff and Barnes for the Slovenian Presidency in which the EU and its member states are referred to as being 'amongst the most progressive [...] in the world when it comes to gender,' and the EU is viewed as distinct from other organizations because of its 'commitment to and progress on gender equality and human rights' in policy fields such as development' (Sherriff and Barnes, 2008: 4). This case illustrates that previously agreed upon policies and firmly established institutions do not only shape implementation, they can also drive change.

\subsection{Same decision-making rule - different influence resulting from different extent of membership}

Lastly, the influence of decision-making rules explains the less dynamic approach in the OSCE, albeit in a different way than the literature suggests (Hanrieder, 2014). What distinguishes the OSCE and the ESDP is not the rule itself - after all, consensus decisions are required in both cases - but the way in which it becomes effective as a result of the varying extent of membership. Whereas in the case of the EU, individual states such as Sweden, France, or Slovenia saw the inclusion of gender in the ESDP as an opportunity to raise the organization's profile and set it apart from the UN, the OSCE's wider membership, and especially the veto of member states that are less in favor of UNSCR 1325, appear to have restricted the 
implementation of UNSCR 1325. One important veto player is Russia, whose Permanent Representative, for instance, stated that 'it should not be forgotten that Resolution 1325 is applicable only in certain situations, and therefore we cannot agree with its excessive promotion in the OSCE and especially its extremely broad interpretation. We take the position that the leading role in this regard should remain with the United Nations' (OSCE Delegation of the Russian Federation, 2016: 2). Since 2014, the Russian Delegation has blocked several attempts to negotiate an action plan on the women, peace, and security agenda (Lukatela, 2016: 53), most 'likely linked to the utility it sees in using gender equality to push back against the overall human rights agenda and the human dimension work where it encroaches on Russian interests' (Lukatela, 2016: 57). These vested interests have blocked progress related to UNSCR 1325 in the OSCE. We could not detect dynamics of this kind in the EU.

\section{Conclusions}

The comparison of the ways in which the OSCE and the EU introduced UNSCR 1325 into their security policies has revealed interesting similarities and differences. In response to efforts from reform coalitions, both organizations started to engage with the resolution, but they pursued different paths toward its implementation. The OSCE's approach resembles an incremental conversion of its existing gender policy, which has since been 'locked in' because of opposition under the prevailing consensus rule. The EU's approach, on the other hand, can be likened to a layering-on of a new, comparatively comprehensive and specific policy alongside existing gender policies in other policy areas.

Conventional and feminist historical institutionalism help to make sense of the different responses of the two organizations by drawing attention to entrenched norms and rules, some of them gendered, the activities of feminist reform coalitions, and the constraining and enabling factors with which these coalitions are faced. In the case of the OSCE, gender policy legacies 
proved to be relatively change-resistant because there was little interaction between internal and external change agents and opposition from individual participating states. In the case of the EU, gender policy legacies, in combination with formal and informal rules related to external interaction, benefited the reform coalition and facilitated the adoption of the more specific and dynamic Comprehensive Approach.

These are important findings, both in theoretical and practical terms. As regards theory, they lend themselves to further research on gender-mainstreaming in security organizations. In this study, we focused primarily on implementation at the policy level, but it would also be of importance to examine how well the factors we have identified travel across different levels and, for example, influence implementation into practices at the level of field missions and operations. Also, what role do these factors play in other regional security organizations, such as NATO where UNSCR 1325 has started to take a hold as well (Wright, 2016)? With respect to the implications for policy, there is reason for gender advocates to be cautiously optimistic. While previous exposure of institutions to gender may not guarantee the success of gendermainstreaming activities, support from external actors can help to overcome internal opposition and equality-adverse gender norms and rules. Even in cases where internal opposition is currently blocking substantial change, external support may help internal gender advocates to work creatively around such opposition and implement piecemeal changes that contribute over time to changed outcomes.

\section{Funding}

This work was supported by the Folke Bernadotte Academy, Sweden. 


\section{References}

Barnett, Michael and Martha Finnemore (2004) Rules for the World: International Organizations in Global Politics. Ithaca: Cornell University Press.

Capoccia, Giovanni and R. Daniel Kelemen (2007) The Study of Critical Junctures: Theory, Narrative, and Counterfactuals in Historical Institutionalism. World Politics 59(3): 341-369.

Chappell, Louise and Georgina Waylen (2013) Gender and the Hidden Life of Institutions. Public Administration 91(3): 599-615.

Council of the European Union (2006) Check List to Ensure Gender Mainstreaming and Implementation of UNSCR 1325 in the Planning and Conduct of ESDP Operations. Brussels: 12086/06, available at: http://www.eupolcopps.eu/sites/default/files/u2/Checklist\%20on\%20UNSCR\%201325\%2 0in\%20ESDP\%20Ops.pdf (last access: 02 September 2013).

Council of the European Union (2008) Comprehensive Approach to the EU Implementation of the United Nations Security Council Resolution 1325 and 1820 on Women, Peace and Security. Brussels: 15671/1/08 REV 1, available at: http://www.consilium.europa.eu/ueDocs/cms_Data/docs/hr/news187.pdf (last access: 23 August 2013).

Council of the European Union (2010) Indicators for the Comprehensive approach to the EU implementation of the United Nations Security Council Resolutions 1325 and 1820 on women, peace and security. Brussels, available at: http://register.consilium.europa.eu/pdf/en/10/st11/st11948.en10.pdf (last access: 02 September 2013).

Dembinski, Matthias and Jutta Joachim (2014) Civil society and the European common security and defence policy. European Security 23(4): 449-465. 
Elgström, Ole (2000) Norm negotiations: The construction of new norms regarding gender and development in EU foreign aid policy. Journal of European Public Policy 7(3): 457-476.

European Parliament (2000) European Parliament resolution on participation of women in peaceful conflict resolution. Brussels: 2000/2025(INI), available at: http://www.europarl.europa.eu/sides/getDoc.do?pubRef=-//EP//TEXT+TA+P5-TA-20000541+0+DOC+XML+V0//EN\&language=EN (last access: 15 February 2016).

European Parliament (2009) Gender Mainstreaming and Empowerment of Women in EU's External Relations Instruments. Brussels: EXPO/B/AFET/2008/67, available at: http://www.honvedelem.hu/files/9/8008/sede_action_plan_on_gender_mainstreamingfinal_version.pdf (last access: 02 September 2013).

European Parliament (2010) Implementation of EU Policies following the UN Security Council Resolution 1325. Brussels: EXPO/B/DROI/2009/26.

Fioretos, Orfeo (2011) Historical Institutionalism in International Relations. International Organization 65(2): 367-399.

Guerrina, Roberta and Katharine A. M. Wright (2016) Gendering normative power Europe: Lessons of the Women, Peace and Security agenda. International Affairs 92(2): 293-312.

Gya, Giji (2007) The importance of gender in ESDP. Brussels: European Security Review 34, available at: http://www.europarl.europa.eu/meetdocs/2004_2009/documents/dv/170/170707/170707isi sgender_en.pdf (last access: 15 February 2016).

Hanrieder, Tine (2014) Gradual Change in International Organisations: Agency Theory and Historical Institutionalism. Politics 34(4): 324-333.

Hawkins, Darren G., David A. Lake, Daniel A. Nielson and Michael J. Tierney (2006) Delegation Under Anarchy: States, International Organizations, and Principal-Agent Theory. In Darren G. Hawkins, David A. Lake, Daniel A. Nielson and Michael J. Tierney 
(eds) Delegation and Agency in International Organizations. Cambridge: Cambridge University Press, 3-38.

Koops, Joachim A. (2012) NATO's Influence on the Evolution of the European Union as a Security Actor. In Oriol Costa and Knud E. Jørgensen (eds) The Influence of International Institutions on the EU. Basingstoke: Palgrave Macmillan, 155-185.

Kronsell, Annica (2016) Sexed Bodies and Military Masculinities: Gender Path Dependence in EU's Common Security and Defense Policy. Men and Masculinities 19(3): 311-336.

Lukatela, Ana (2016) Implementing the Women, Peace and Security Agenda in the OSCE: the power of middle management norms in the policy process. Security and Human Rights 27(1-2): 45-58.

Mackay, Fiona, Meryl Kenny and Louise Chappell (2010) New Institutionalism Through a Gender Lens: Towards a Feminist Institutionalism? International Political Science Review 31(5): 573-588.

Mahoney, James and Kathleen Thelen (2010) A Theory of Gradual Institutional Change. In James Mahoney and Kathleen Thelen (eds) Explaining Institutional Change: Ambiguity, Agency, and Power. Cambridge et al.: Cambridge University Press, 1-37.

Moschella, Manuela and Antje Vetterlein (2014) International organizations and organizational fields: explaining policy change in the IMF. European Political Science Review 6(1): 143165.

Ormhaug, Christin (2014) OSCE Study on National Action Plans on the Implementation of the United Nations Security Council Resolution 1325. Vienna: OSCE, available at: http://www.osce.org/secretariat/125727?download=true (last access: 08 July 2016).

OSCE (2004) Action Plan for the Promotion of Gender Equality. Vienna: MC.DEC/14/04.

OSCE (2005) Decision No. 14/05: Women In Conflict Prevention, Crisis Management and Post-Conflict Rehabilitation. Vienna: MC.DEC/14/05. 
OSCE (2010) The OSCE and 'Women, Peace and Security': 10 Years after the adoption of UNSCR 1325. Vienna: High-Level Tripartite Meeting, 14 June 2010, available at: http://www.osce.org/gender/70694?download=true (last access: 08 July 2016).

OSCE (2015) In Pursuit of Peace and Security: How Gender Makes a Difference. Vienna: Report from the OSCE Security Days, 13 November 2015, available at: http://www.osce.org/sg/216776?download=true (last access: 01 April 2017).

OSCE (2000-2015) Annual Reports. Vienna, available at: www.osce.org.

OSCE Delegation of the Russian Federation (2016) Statement by Mr. Alexander Lukashevich, Permanent Representative of the Russian Federation, at the 1092nd meeting of the OSCE Permanent Council, Vienna: OSCE, available at: http://www.osce.org/pc/227906?download=true (last access: 08 July 2016).

OSCE and Inclusive Security (2016) Designing inclusive strategies for sustainable security: results-oriented national action plans on Women, Peace and Security. Vienna, available from: http://www.osce.org/secretariat/294731?download=true [Accessed 3 September 2017].

Park, Susan (2006) Theorizing Norm Diffusion Within International Organizations. International Politics 43(3): 342-361.

Pierson, Paul (2000) Increasing Returns, Path Dependence, and the Study of Politics. American Political Science Review 94(2): 251-267.

Sherriff, Andrew and Karen Barnes (2008) Enhancing the EU Response to Women and Armed Conflict: With particular Reference to Development Policy: Study for the Slovenian EU Presidency. Brussels: European Centre for Development Policy Management, available at: http://www.europarl.europa.eu/document/activities/cont/200805/20080507ATT28495/200 80507ATT28495EN.pdf (last access: 02 September 2013). 
Sjoberg, Laura (2013) Gendering Global Conflict: Toward a Feminist Theory of War. New York: Columbia University Press.

Squatrito, Theresa, Thomas Sommerer and Jonas Tallberg (2016) Transnational Access to International Organizations, 1950-2010: Structural Factors and Critical Junctures. In: Rixen, Thomas, Lora Anne Viola and Michael Zürn (eds) Historical Institutionalism and International Relations: Explaining Institutional Development in World Politics. Oxford: Oxford University Press, 165-196.

UN Security Council (2000) Resolution 1325, adopted at 4213 $3^{\text {th }}$ meeting, 31 October 2000.

UN Security Council (2009), Resolution 1889, adopted at $6196^{\text {th }}$ meeting, 5 October 2009.

Waylen, Georgina (2009) What Can Historical Institutionalism Offer Feminist Institutionalists? Politics \& Gender 5(2): 245-253.

Weiner, Elaine and Heather MacRae (2014) The persistent invisibility of gender in EU policy: Introduction. European Integration online Papers (EIoP), 18: Art. 3.

Woodward, Alison (2003) Building velvet triangles: gender and informal governance. In Christiansen, Thomas and Simona Piattoni (eds) Informal Governance in the European Union. Edward Elgar: Cheltenham, 76-93.

Woodward, Alison E. and Anna van der Vleuten (2014) EU and the Export of Gender Equality Norms: Myths and Facts. In: Anna van der Vleuten, A. van Eerdewijk and C. Roogeband (eds) Gender Equality Norms in Regional Governance: Transnational Dynamics in Europe, South America and Southern Africa. Basingstoke: Palgrave Macmillan, 67-92.

Wright, Katharine A. M. (2016) NATO'S adoption of UNSCR 1325 on Women, Peace and Security: Making the agenda a reality. International Political Science Review 37(3): 350361.

Zürn, Michael (2016) Historical Institutionalism and International Relations - Strange Bedfellows? In: Rixen, Thomas, Lora Anne Viola and Michael Zürn (eds) Historical 
Institutionalism and International Relations: Explaining Institutional Development in

World Politics. Oxford: Oxford University Press, 199-228.

\section{Author biographies}

Anne Jenichen is Lecturer in Politics and International Relations at Aston University, Birmingham (UK). Her research interests include international institutions, multi-level governance, gender and politics, religion and politics, and international human rights, primarily in Europe.

Jutta Joachim is Senior Lecturer of International Relations at Radboud University, Nijmegen (Netherlands). Her areas of expertise are international security, international organizations, non-state actors, and gender and international relations.

Andrea Schneiker is Junior Professor of Political Science at the University of Siegen (Germany). Her research focuses on state and non-state actors and on gender in international security.

\footnotetext{
${ }^{\mathrm{i}}$ Since then, the resolution has been followed up with seven additional resolutions related to the subject, including UNSCR 1889 adopted in 2009, which demands from 'Member States, international and regional organisations to take further measures to improve women's participation during all stages of peace processes' (UN Security Council, 2009: art. 1).

ii The first Gender Adviser had been appointed in 1999. In 2011, this position was turned into a position at the ambassadorial level and three additional Gender Advisers were introduced, one for each dimension of the organization's security policy.

iii Authors' interview, 19 November 2015.

iv Authors' interviews, 19 November 2015, 10 December 2015, 8 January 2016.

' Authors' interview, 10 December 2015.

vi Authors' interview, 19 November 2015.

vii Authors' interviews with NGO and OSCE representatives, November 2015.

viii See, for example, the website of the Swedish government on its gender equality policies: http://www.government.se/government-policy/gender-equality/ (last access on 27 November 2017).

ix Authors' interviews with OSCE representatives, November and December 2015.

x Authors' interview, 5 November 2015.
} 